\title{
PENERAPAN MEDIASI DALAM PENYELESAIAN SENGKETA WANPRESTASI HUTANG PIUTANG DI PENGADILAN NEGERI GIANYAR
}

\author{
Putri Anggun Puspasari, Ni Luh Made Mahendrawati, Desak Gde Dwi Arini \\ Fakultas Hukum, Universitas Warmadewa
}

\begin{abstract}
ABSTRAK
Mediasi merupakan bentuk alternative penyelesaian sengketa. Mediasi telah tumbuh dan berkembang, berjalan dengan cepatnya, keinginan manusia atau masyarakat untuk menyelesaikan sengketa secara cepat, dan memuaskan kedua belah pihak yang bersengketa, Menurut PERMA No 1 Tahun 2016 Tentang Prosedur Mediasi di Pengadilan menentukan bahwa Mediasi merupakan cara menyelesaian sengketa secara damai, cepat, tepat, dan efektif, dapat membuka akses yang lebih luas kepada Para Pihak yang bersengketa untuk memperoleh penyelesaian dari perkaranya, dan mendapatkan rasa keadilan. Hutang piutang merupakan perjanjian menimbulkan hak dan kewajiban antara kreditur dengan debitur yang bertimbal balik. Hutang piutang diatur dalam dalam Bab Ketiga Belas Buku Ke Tiga KUH Perdata, dalam Pasal 1754 KUH Perdata. Permasalahannya adalah bagaimana penerapan mediasi dalam penyelesaian sengketa wanprestasi hutang piutang di Pengadilan Negeri Gianyar? dan apa saja faktor - faktor yang mempengaruhi tidak berhasilnya mediasi di Pengadilan Negeri Gianyar? Penelitian yang di gunakan adalah penelitian hukum empiris, yaitu melihat masyarakat dengan artian nyata. Dan pendekatan masalah yang digunakan yaitu pendekatan kasus - kasus yang berada di Pengadilan Negeri Gianyar. Kesimpulan yang di dapat dari penelitian ini adalah bahwa penerapan mediasi di Pengadilan Negeri Gianyar sudah sesuai dengan Peraturan Mahkamah Agung No 1 Tahun 2016, dan faktor - faktor yang menghambat proses mediasi di Pengadilan Negeri Gianyar yaitu kedua belah pihak yang berperkaratidak datang dalam proses mediasi sehingga proses mediasi menjadi gagal.

Kata Kunci: Mediasi, Penyelesian Sengketa, Hutang Piutang, Wanprestasi.
\end{abstract}

\begin{abstract}
Mediation is an alternative form of dispute resolution. Mediation has grown and developed, running fast, the desire of humans or the community to resolve disputes quickly, and satisfying both parties to the dispute, According to PERMA No. 1 of 2016 concerning Procedure for Mediation in the Court determining that Mediation is a way to settle disputes peacefully, quickly, right, and effective, can open wider access to the parties to the dispute to obtain a settlement of the case, and get a sense of justice. Accounts payable is an agreement that creates rights and obligations between creditors and debtors who are reciprocal. Accounts payable is regulated in Chapter Thirteenth of the Third Book of the Civil Code, in Article 1754 of the Civil Code. The problem is how is the application of mediation in resolving disputes over debt defaults in the Gianyar District Court? And what are the factors that influence the success of mediation in the Gianyar District Court? The research used is empirical legal research, which is looking at society in the real sense. And the problem approach used is the approach of cases in the Gianyar District Court. The conclusion obtained from this study is that the application of mediation in the Gianyar District Court is in accordance with Supreme Court Regulation No. 1 of 2016, and the factors that hinder the mediation process in the Gianyar District Court, namely both litigants do not come in the mediation process so the mediation process failed.
\end{abstract}

Keywords: Mediation, Dispute Resolution, Debt Receivables, Default.

\section{PENDAHULUAN}

Hutang piutang merupakan perjanjian yang ada sesuatu di dalam nya yaitu hak dan kewajiban anatara kreditur dan debitur yang bertimbal balik. Artinya nya perjanjian hutang piutang yaitu pihak kreditur memberikan pinjaman uang kepada pihak debitur, dan debitur wajib mengembalikan uang nya dalam waktu yang sudah di perjanjikan atau ditentukan disetai bunga. Setiap pengembalian uang yang berupa hutang dari debitur, debitur dapat mengembaikan hutang nya dengan cara menyicil atau mengangsur setiap bulan (Supramono, 2013).

Begitu banyak kejadian yang terjadi di bidang pinjam meminjam uang atau hutan piutang, pengembalian hutang yang wajib dibayar oleh debitur acapkali tidak sesuai dengan apa yang diperjanjikan oleh kreditur. Debitur boleh membayar angsuran hutang secara menyicil atau bembayar 
dengan cara sedikit demi sedikit, dan adakala nya debitur tidak dapat membayarnya lagi. Dibidang perbankan keadaan ini juga disebut kredit macet. Setiap di dunia perbangkan, ada kalanya debitur yang hutang nya sudah jatuh tempo tidak dibayar sama sekali di dasari oleh beberapa faktor, tetapi beberapa hari kemudian bisa dibayar dan dilunasi. Hutang yang sama sekali tidak dibayar termasuk perbuatan yang dinamakan wanprestasi atau ingkar janji (Perwitasari, 2013). Berbagai alasan debitur melakukan wanprestasi seperti, usaha nya merugi, bencana alam, tidak dapat memutar uang, dan masih banyak lagi. Wanprestasi adalah bentuk pelanggaran yang di atur dalam KUH Perdata yaitu perjanjian hutang piutang sebagai sumber persengketaan antara para pihak kreditur dan pihak debitur, kreditur menangih hutangnya dan di sisi lain debitur tidak dapat memenuhi kewajiban nya yaitu membayar hutangnya.

Pengadilan sebagai pilihan penyelesaian sengketa yaitu dengan proses mediasi. Mediasi memang telah terbukti mampu menyelesaikan sengketa secara cepat, tepat, dan efektif menghasilkan, hingga dapat mendapatkan sekepakatan antara dua belah pihak (penggugat dan tergugat) (Meuraksa, 2017). Mediasi mampu meringankan pemeriksaan perkara di Pengadilan Negeri dan mampu mendorong para pihak agar duduk bersama menyelesaikan permasalahan yang ada agar cepat berakhir, dengan bantuan mediator (Abbas, 2017). Dalam mediasi tidak ada kata kalah menang melainkan kesepakatan bersama antara kedua belah pihak. Mediasi di atur dalam PERMA No 1 Tahun 2016 tentang Proses Mediasi di Pengadilan, untuk menyelesaikan sengketa hutang piutang harus di selesaikan dengan cara mediasi karena mediasi dapat memberikan rasa keadilan antara pihak kreditur dan pihak debitur, proses yang cukup gampang bisa mempertemukan kedua belah pihak membicarakan permasalah yang ada dengan baik baik, dan menjauhkan dari rasa benci dan ketidakadilan.

Mediasi di Indonesia pada hakekatnya di kenal dalam beberapa peraturan diantaranya:

a. Undang-undang No 30 tahun 1999 tentang Alternatif Penyelesaian Sengketa.

b. Peraturan Mahkamah Agung No. 1 tahun 2016 tentang Prosedur Mediasi di Pengadilan.

Menurut informan Bapak Wawan Edi Prastiyo, S.H, M.H. keunggulan dari proses mediasi adalah:

1. Mendapatkan kesepakatan antara kedua belah pihak (antara penggugat dan tergugat) sehingga pekara cepat selesai dan dibantu oleh mediator.

2. Tidak ada yang kalah dan tidak ada yang menang karena mediasi merupakan kesepakatan antara kedua belah pihak.

3. Proses nya relative lebih mudah, cepat, tepat dan efektif. Jika kedua belah pihak mempunyai itikad baik untuk berdamai.

4. Tidak di kenakan biaya dalam proses mediasi di pengadilan, jika menggunakan kuasa hukum bisa di kenakan biaya untuk membayar kuasa hukum tersebut.

Pengadilan Negeri Gianyar sudah sejak dahulu memang sudah menjadi salah satu pengadilan tingkat pertama khususnya di Bali (Indonesia) sekaligus sebagai salah satu pelaksanaan kekuasaan kehakiman telah menerapkan mediasi dalam penyelesaian sengketa perdata. tentang:

Sengketa perdata di Pengadilan Negeri Gianyar secara garis besar diantaranya mencangkup

1. pembagian harta,

2. perceraian,

3. wanprestasi,

4. hutang piutang,

5. perbuatan melawan hukum $(\mathrm{PMH})$,

6. perjanjian,

7. waris,

8. tanah.

Namun penyelesaian sengketa perdata melalui mediasi di Pengadilan Negeri Gianyar belum bisa mencapai hasil optimal dalam menangani kasus tersebut. Sehingga dalam upaya mengoptimalisasikan mediasi sebagai sarana penyelesaian sengketa perdata para hakim di Pengadilan Negeri Gianyar sudah seharusnya selalu mengupayakan dua pihak yang bersengketa untuk menempuh jalur damai, karena jalur damai akan mempercepat proses penyelesai sengketa dan mengakhirinya atas kehendak kedua belah pihak (tergugat maupun penggugat). Mediasi juga perlu dimaksimalkan penerapannya karena pada prinsipnya suatu peraturan dibuat adalah untuk menjalankan, demikian juga hal dengan Peraturan Mahkamah Agung No 1 Tahun 2016 yang mengatur tentang prosedur mediasi di pengadilan dalam hal ini di Pengadilan Negeri Gianyar. 
Pemberlakuan mediasi sangatlah diharapkan dapat memperluas akses bagi para pihak untuk memperoleh rasa keadilan antara kedua belah pihak. Rasa keadilan tidak hanya dapat diperoleh melalui proses litigasi, tetapi juga melalui proses musyawarah mufakat oleh para pihak. Dengan diberlakukannya mediasi ke dalam sistem peradilan formal, masyarakat pencari keadilan pada umumnya dan para pihak yang bersengketa pada khususnya dapat terlebih dahulu mengupayakan penyelesaian atas sengketa mereka melalui pendekatan musyawarah mufakat yang dibantu oleh seorang penengah yang disebut mediator.

Peraturan Mahkamah Agung No 1 tahun 2016 tentang prosedur mediasi di pengadilan diharapkan dapat mendorong perubahan cara pandang para pelaku atau pemerintah dalam proses peradilan perdata di seluruh Pengadilan Umum, yaitu hakim dan advokat, bahwa lembaga pengadilan tidak hanya memutus, tetapi juga mendamaikan. Peraturan Mahkamah Agung tentang Mediasi memberikan panduan untuk dicapainya perdamaian dan tidak ada lagi rasa ketidakadilan yang dirasakan oleh kedua belah pihak.

Adapun rumusan masalah yang akan dibahas ialah bagaimana penerapan mediasi dalam penyelesaian sengket wanprestasi hutang piutang di Pengadilan negeri Gianyar? Dan apa saja factorfaktor yang mempengaruhi tidak berhasilnya mediasi di Pengadilan Negeri Gianyar? Dengan demikian, tujuan penelitian yang akan dicapai ialah untuk mengetahui dan memahami penerapan mediasi dalam penyelesaian sengketa perdata wanprestasi hutang piutang di Pengadilan Negeri Gianyar dan untuk mengetahui dan memahami faktor-faktor yang mempengaruhi tidak berhasilnya pelaksaan mediasi di Pengadilan Negeri Gianyar.

\section{METODE PENELITIAN}

Penelitian yang dilakukan menggunakan tipe penelitian hukum empiris, Penelitian hukum empiris adalah suatu metode penelitian hukum yang berfungsi untuk melihat hukum dalam artian nyata atau terjun secara langsung ke dalam kehidupan bermasyarakat, dan meneliti bagaimana bekerjanya hukum di lingkungan masyarakat (Sunggono, 2006). Pendeketan masalah ini dilakukan dengan melakukan telaah pada kasus - kasus yang berkaitan dengan isu hukum yang dihadapi (Marzuki, 2010). Mengidentifikasi kasus - kasus tentang wanprestasi yang sedang berjalan di Pengadilan Negeri Gianyar atau dengan kasus - kasus yang telah mendapat putusan pengadilan. Bahan hukum yang digunakan terdiri dari bahan hukum primer dan sekunder (Soekanto, 2007).

\section{HASIL DAN PEMBAHASAN}

\section{Penerapan Mediasi dalam Penyelesaian Sengketa Wanprestasi Hutang Piutang di} Pengadilan Negeri Gianyar

Penyelesaian sengketa melalui litigasi atau pun melalui sistem peradilan lainnya dipandang sebagai jalan terbaik dalam menyelesaikan sengketa. Sehingga setiap kali muncul konflik atau permasalahan maka yang timbul dalam pikiran adalah penyelesaiannya harus melalui pengadilan. Padahal penyelesaian perkara di pengadilan cenderung berlangsung berlarut - larut, memakan waktu yang lama dan biaya mahal. Selain itu pengadilan menganut sistem win-lose solution dalam penyelesaian perkara. Sehingga akan ada pihak yang diuntungkan dan dirugikan seperti kalah dan menang hal ini terkadang menimbulkan rasa ketidak puasan salah satu pihak karena merasa putusan yang di jatuhi oleh hakim tidak adil.

Berdasarkan hasil wawancara pada tanggal 3 Desemember 2018 pukul 09.00 WITA bertempat di Pengadilan Negeri Gianyar, dengan Wawan Edi Prastiyo SH, MH selaku Hakim Anggota dan selaku Mediator dari kasus wanprestasi dalam proses mediasi di Pengadilan Negeri Gianyar mengatakan bahwa Penerapan Mediasi dalam perkara perdata di Pengadilan Negeri Gianyar sudah sesuai dengan Peraturan Mahkamah Agung No 1 Tahun 2016. Proses mediasi di Pengadilan Negeri Gianyar dapat dibagai menjadi dua tahap, yakni pra mediasi dan tahap mediasi.

Mediasi dilakukan secara tertutup dan dilaksanakan dengan sungguh - sungguh disalah satu ruangan khusus di Pengadilan Negeri Gianyar. Namun karena adanya beberapa factor yang belum terpenuhi mengakibatkan tingkat efektifitasnya masih rendah. Hasil mediasi yang selama ini dilaksanakan di Pengadilan Negeri Gianyar yaitu jarang ada kesepakatan perdamaian antara para pihak dalam mediasi.

Para pihak yang dapat mencapai kesepakatan dalam mediasi masih sedikit. Optimalisasi mediasi dalam perkara perdata di Pengadilan Ngeri Gianyar terus dilakukan, hal ini dilakukan demi memenuhi 
tujuan PERMA Mediasi yakni menekan perkara di Pengadilan tingkat pertama dan menekan perkara di tingkat banding maupun kasasi.

Fungsi pengadilan dalam menyelesaikan perkara sesuai dengan kebutuhan keadilan para pihak yang bersengketa. Peraturan Mahkamah Agung Nomor 1 Tahun 2016 (PERMA), karena PERMA sifatnya wajib di setiap Pengadilan Negeri yang dalam menangani kasus perdata yang dilakukan dengan cara mediasi, dan dalam hal ini telah dicantumkan beberapa pasal yang terkait dan sesuai dengan pokok permasalahan yang terdapat dalam kasus - kasus sengketa perdata. Dan apabila dalam suatu perkara perdata tidak mengikuti tahap mediasi, maka perkara tersebut dapat dinyatakan batal demi hukum.

Berdasarkan hasil wawancara pada tanggal 3 Desember 2018 pukul 11.00 WITA bertempat di Pengadilan Negeri Gianyar, dengan Ida Ayu Andari Utami, S.H. selaku Panitera yang menangani kasus wanprestasi dalam proses mediasi di Pengadilan Negeri Gianyar, mengatakan bahwa Mediasi itu baik untuk dilakukan terlebih dulu sebelum perkara diperiksa oleh hakim. Mediasi baik untuk ditempuh karena memiliki berbagai macam keuntungan dalam pelaksanaannya diantaranya proses penyelesaiannya lebih cepat dari pada litigasi, biaya relatif murah, hubungan kekeluargaan tetap terjaga, dan sebagainya.

Penerapan mediasi di Pengadilan Negeri Gianyar sudah sesuai dengan PERMA No 1 Tahun 2016. Jumlah sengketa yang dapat diselesaikan melalui mediasi hanya berkisar antara 20-30\%.

Sengketa yang ditangani oleh Pengadilan Negeri Gianyar yaitu sengketa hak waris, tanah, perceraian, wanprestasi, dan lain sebagainya. Sengketa yang berhasil diselesaikan melalui mediasi diantaranya yaitu sengketa tentang wanprestasi. Tetapi masih ada sengketa yang didamaikan masih relatif rendah sengketa yang dapat didamaikan melalui mediasi masih sedikit karena hal ini tergantung dari para pihak di mana banyak para pihak yang tidak mau mediasi.

Masyarakat belum paham tentang mediasi, bahwa mediasi akan terus dilakukan selama perkara belum diputus oleh hakim. Hambatan yang ditemui di Pengadilan Negeri Gianyar dalam menyelesaikan sengketa melalui mediasi yaitu salah satu pihak sering tidak hadir dalam mediasi, pihak prinsipal selalu menguasakan kepada kuasa hukum dalam melakukan mediasi. Tindakan yang dilakukan untuk mengatasi hambatan tersebut yaitu menyarankan kepada kuasa hukum agar para pihak prinsipal sendiri yang datang pada saat mediasi.

Hasil dari wawancara yang dilakukan oleh penulis dengan Hakim dan Panitera, Pengadilan Negeri Gianyar, bisa ditarik kesimpulan bahwa penerapan mediasi di Pengadilan Negeri Gianyar sudah cukup optimal, dan hasil dari keberhasilannya proses mediasi disertai dengan ketentuan hukum yaitu berupa akta penetapan dan akta kesepakatan perdamaian.

Menurut Wawan Edi Prastiyo, akhir dari proses mediasi di Pengadilan Negeri Gianyar harus berisi akta penetapan adalah: penetapan ialah juga pernyataan hakim yang dituangkan dalam bentuk tertulis dan diucapkan oleh hakim dalam sidang, sebagai hasil dari pemeriksaan perkara pemohonan (voluntair).

Akta kesepakatan perdamaian adalah kesepakatan hasil Mediasi dalam bentuk dokumen yang memuat ketentuan penyelesaian sengketa yang ditandatangani oleh Para Pihak dan Mediator. Dengan dikuatkannya akta kesepakatan perdamaian dalam akta perdamaian, maka kesepakatan perdamaian itu memiliki kekuatan eksekutorial atau memiliki kekuatan hukum sama dengan putusan pengadilan.

Pengukuhan kesepakatan perdamaian menjadi akta perdamaian oleh hakim permeriksa perkara tidak bersifat wajib tetapi bersifat pilihan dari para pihak yang bersengketa. Yaitu tergantung ada atau tidaknya permintaan dari para pihak yang bersengkata kepada hakim pemeriksa perkara.

\section{Faktor Faktor yang Mempengaruhi Tidak Berhasilannya Pelaksanaan Mediasi Di Pengadilan Negeri Gianyar}

Berdasarkan hasil wawancara pada tanggal 3 Desember 2018 pukul 09.00 WITA bertempat di Pengadilan Negeri Gianyar, dengan Wawan Edi Prastiyo SH., MH selaku Hakim Anggota dan selaku Mediator mengatakan bahwa faktor - faktor yang mempengaruhi tidak berhasilnya mediasi di Pengadilan Negeri Gianyar adalah:

1. Ketidak hadiran para pihak yang bersengketa

Kehadiran para pihak dalam proses mediasi sangatlah menentukan, karena tidak mungkin proses mediasi dapat dilaksanakan, jika salah satu pihak/ para pihak tidak hadir pada pertemuan yang telah dijadualkan. Hal inilah yang sering terjadi di Pengadilan Negeri Gianyar sehingga berpengaruh pada minimnya jumlah perkara yang berhasil dimediasi. Mediasi hanya wajib 
dilakukan di saat kedua belah pihak yang berperkara hadir dalam pertemuan mediasi. Jadi ketidakhadiran para pihak dalam mediasi dapat mengesampingkan kewajiban mediasi itu sendiri. Pemahaman ini muncul dengan dasar bahwa secara logis karena hanya dalam kondisi hadirnya kedua belah pihak kesepakatan damai dapat dilakukan. Sesuai dengan Peraturan Mahkamah Agung No 1 Tahun 2016, para pihak seharusnya datang dengan secara suka rela agar masalah yang alami cepat selesai dan para pihak dengan cepat mendapatkan titik temu dari masalah yang di hadapi, dan mendapatkan rasa keadilan.

2. Jumlah hakim mediator yang bersertifikat masih minim.

Salah satu faktor berhasilnya atau tidaknya suatu proses mediasi adalah keahlian mediator dalam memberikan solusi atau penwaran pemecahan masalah kepada para pihak yang bersengketa. Karena sebagian dari hakim di Pengadilan Negeri Gianyar masih belum ada yang bersertifikat, mereka menjalankan tugas sebagai mediator berdasarkan ilmu yang mereka peroleh dari seminar, buku - buku serta pengalaman dalam menjalani medisi selama ini.

3. Kendala dalam proses mediasi

Kendala yang ditemukan dalam pelaksanaan mediasi pada Pengadilan Negeri Gianyar adalah sulitnya mediator untuk memberikan pengertian dan pemahan kepada para pihak yang bersengketa untuk menemukan titik temu dari permasalahan mereka. Cara mengatasi kendala ini adalah dituntutnya peran aktif dari mediator dengan bekal kemampuan yang dimiliki nya, mediator dapat mengendalikan proses mediasi untuk menuntut para pihak mencapai sebuah kesepakatan.

4. Proses mediasi merupakan hal yang baru

Mediasi merupakan hal yang baru dalam penyelesaian sengketa perdata melalui pengadilan. Mediasi baru di terapkan secara efektif untuk seluruh Pengadilan Negeri sejak keluarnya Perma No. 1 tahun 2016. Hal ini menyebabkan masih kurang efektifnya proses mediasi untuk mencapai perdamaian.

\section{SIMPULAN DAN SARAN}

\section{Simpulan}

1) Penerapan mediasi di Pengadilan Negeri Gianyar telah sesuai dengan Peraturan Mahkamah Agung No. 1 tahun 2016 dan Majelis Hakim Pengadilan Negeri Gianyar dalam hal ini telah menjalankan tugasnya dengan baik dan juga telah menjalankan serta memenuhi Peraturan Mahkamah Agung Nomor 1 Tahun 2016 (PERMA), karena PERMA sifatnya wajib di setiap Pengadilan Negeri yang dalam menangani kasus perdata yang dilakukan dengan cara mediasi, dan dalam hal ini telah dicantumkan beberapa pasal yang terkait dan sesuai dengan pokok permasalahan yang terdapat dalam kasus-kasus sengketa perdata. Dan apabila dalam suatu perkara perdata tidak mengikuti tahap mediasi, maka perkara tersebut dapat dinyatakan batal demi hukum.

2) Faktor - faktor tidak berhasilnya pelaksaan proses mediasi di Pengadilan Negeri Gianyar ialah faktor utama terdapat pada para pihak yang bersengketa sering tidak hadir dalam proses mediasi pihak prinsipal selalu menguasakan kepada kuasa hukum dalam melakukan mediasi, sehingga proses mediasi menajdi gagal. Dan karena sulitnya mediator untuk memberikan pengertian dan pemahaman kepada para pihak yang bersengketa untuk menemukan titik temu dari permasalahan mereka, sehingga menyebabkan proses pelaksanaan mediasi tersebut menjadi gagal.

\section{Saran}

1) Untuk Pemerintah

Hendaknya Pemerintah mensosialisasikan tentang Praturan Mahkamah Agung No 1 Tahun 2016 Tentang Prosedur Mediasi di Pengadilan, pemerintah harus memberikan penjelasan mengenai makna dan tujuan mediasi kepada masyarakat. Pengadilan Umum maupun Pengadilan Agama harus mengimplementasi hukum dapat lebih memaksimalkan potensi yang 
ada dalam PERMA No 1 Tahun 2016 demi meminimalisir terjadiya penumpukan perkara di tiap - tiap pengadilan yang ada di Indonesia.

2) Untuk Perusahaan

Diharapkan untuk seluruh perusahaan di Indonesia yang mengalami sengketa perdata diwajibkan mengikuti proses mediasi terlebih dahulu. Sehingga dalam penyelesaian sengketa tidak hanya sekedar melakukan proses mediasi sebagai formalitas untuk menghindari ancaman batal demi hukum, tetapi hendaknya menyelesaiakan sengketa sesuai dengan tujuan mediasi sehingga terpenuhinya rasa keadilan dan bermanfaat bagi para pihak.

3) Untuk Masyarakat

Demi lancarnya sebuah proses mediasi paling tidak para pihak diharapkan dengan sukarela menghadiri dan mengikuti proses mediasi dengan itikad baik sebagaimana sudah ditentukan dalam PERMA No 1 Tahun 2016 tentang Prosedur Mediasi di Pengadilan.

\section{DAFTAR PUSTAKA}

Abbas, S. (2017). Mediasi dalam hokum Syariah, Hukum Adat, Hukum Nasional, Cet ke 3. Cimanggis Depok: PT. Kharisma Putra Utama.

Marzuki, P. M. (2010). Penelitian Hukum (VI). Jakarta: Predana Media Group.

Meuraksa, M. A. E. (2017). Analisis Mediasi dalam Penyelesaian Sengketa Wanprestasi Perjanjian Sewa Menyewa di Pengadilan Negeri Tangerang Dihubungkan Dengan Undang-Undang Nomor 30 Tahun 1999 Tentang Arbitrase dan Alternatif Penyelesaian Sengketa (Analisis Putusan No. 129/PDT.G/201. Jurnal Surya Kencana Dua: DInamika Masalah Hukum Dan Keadilan, 4(1).

Perwitasari, I. (2013). Penyelesaian Perjanjian Pembayaran Hutang Piutang Dengan Bilyet Giro Di Pengadilan Negeri Surakarta (Studi Putusanno.90/Pdt.G/2011/Pn.Ska). Surakarta.

Soekanto, S. (2007). Pengantar Penelitian Hukum. Jakarta: Universitas Indonesia.

Sunggono, B. (2006). Metode Penelitian Hukum. Jakarta: Rajawali Pers.

Supramono, G. (2013). Penyelesaian Sengketa Lingkungan Hidup di Indonesia. Jakarta: Rineka Cipta. 